\title{
Pastoral care to or with sex-starved pregnant women in an African context
}

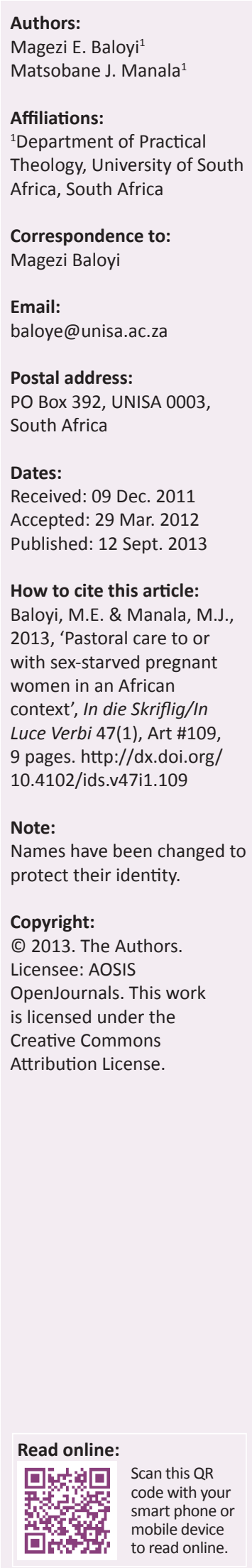

The aim of this article is to highlight some African women's problematic sex life, even in their married lives, as a result of prescribed and lengthy periods of abstinence from sex - especially during pregnancy. Literature studies, especially on Yoruba sexual practices, showed that forced abstinence from sexual activity during pregnancy is rife and that many women seem content with the situation, probably as a result of their internalisation of patriarchal beliefs and values, prescribed as a means of socialisation. This phenomenon of abstinence from sexual intercourse during pregnancy by the women in some African societies is the focus of the study. The article examined the following: views of sex amongst Black African people, medical views of sex and views of sex in Christian tradition. Also examined at length was the phenomenon of abstinence from sex in an African context. The findings led to a critical evaluation of the phenomenon and a search for pastoral guidelines that could facilitate transformation, intimacy and committed sexual life in African families.

Pastorale sorg aan of met seksbebehoewende swanger vrouens in 'n Afrika-konteks. Die doel van hierdie artikel is om die problematiese seksuele lewens van sommige vrouens in Afrika na vore te bring. Die probleme kom voor ten spyte van die feit dat hulle getroud is omdat lang tydperke van onthouding, veral tydens swangerskap, vir hulle voorgeskryf word. 'n Literatuurstudie, veral oor die Yoruba se seksuele praktyke, dui daarop dat gedwonge onthouding van seksuele aktiwiteite gedurendede swangerskap heersend is. Verder kom dit ook voor asof baie vrouens nie daarmee probleme ervaar nie, waarskynlik as gevolg van hulle geïnternaliseerde patriargale oortuigings en waardes, wat vir sosialiseringsdoeleindes voorgeskryf word. Hierdie studie fokus op die verskynsel van onthouding van geslagsomgang gedurende swangerskap deur vrouens in sommige Afrika-gemeenskappe. Die artikel ondersoek die volgende: Swart Afrikane se tradisionele seksbeskouing, die mediese seksbeskouing en die Christelike tradisie se seksbeskouing. Die verskynsel van seksonthouding in 'n Afrika-konteks word ook ondersoek. Die bevindinge lei tot 'n kritiese evaluering van die fenomeen en die soeke na pastorale riglyne wat transformasie, intimiteit en toewyding in seksuele verhoudings in families in Afrika sou kon fasiliteer.

\section{Introduction}

For African people, marriage was and continues to be a highly regarded institution to the extent that they will use any means to protect it. Afolayan (2004:181) notes that amongst the people of South Africa, marriage is the key institution around which the entire social structure revolves. It is true that, when it comes to African traditional conduct in marital life, the couple has very little to say concerning their connubial activities during certain periods. As in every society, African people have certain rules which are used to regulate sexual practices. Folkman and Clatworth (1970:113) concur that all societies regulate human sexual and reproductive behaviour in some way, and the majority of the earth's human inhabitants live in monogamous unions.

One of the rules used to regulate sexual behaviour in some African societies requires abstinence from sexual intercourse during pregnancy. Their respect for marriage made them use different myths and taboos which were thought to be helpful in safeguarding the African marriage. These myths and taboos had moral value for African communities (see Osei n.d.:44). Osei (n.d.) states:

Taboos represent the main source of guiding principles regulating and directing the behaviour of individuals and the community towards the Supreme Being and especially the gods and the ancestors in African traditional societies. (p. 44)

For instance, sex between a husband and wife during pregnancy is forbidden. Hence Labeodan (2007) says:

Most of the women confirmed that once they have 'taken in' [become pregnant], they cease having sexual relationships with their husbands, resuming only after three years have passed and the baby is weaned. (p. 46) 
It is interesting to note that abstinence by women from sex during pregnancy is also practised in some Asian and Latin American cultures. Maldonado (n.d.:30) provides examples of this kind of advice regarding dangers and concerns during pregnancy: 'Avoid going to funerals, avoid reaching over one's head [cord around neck], avoiding drafts of air [Haiti; Latin America; Asia], avoid sexual intercourse [several Asian cultures and Latin America].'

It is evident that, although cultural beliefs and customs were used effectively to convince women to internalise and support the idea of abstinence, it also stems from the fact that women are unable to challenge the gender inequality relating to sexual immorality which men demand because of the traditional superiority of men over women (Boonzaier \& Sharp 1988:159).

This article will therefore research and unveil the practice of exempting or forbidding pregnant women from sexual activities as another way of subjecting and oppressing them. This will be achieved through the study of relevant literature and a few interviews with knowledgeable people in the fields of African customs and traditions and medical science. The population consists of three women who were born and bred in the Limpopo province but who now work in Pretoria. One is a traditional Venda woman, another is a traditional Pedi woman and the third is a traditional Tsonga woman. They are introduced by means of pseudonyms as a means of ensuring confidentiality. The study follows the literature sources relevant to the topic and a small-scale qualitative study using unstructured interviews. The fourth respondent is a medical doctor from Limpopo who was interviewed telephonically.

Important features to be explored in this article are African views of sex in so far as they are relevant to sexual abstinence, especially during pregnancy, medical views of sex in relation to our research topic and views of sex in the Christian tradition. After the study of these views, we will offer a critical evaluation from the Christian and medical perspectives. The last part will attempt to provide some relevant pastoral guidelines and conclusions. The intention of the article is not to be blindly negative to African culture and traditions but to argue that pastoral caregivers should be afforded a space to give advice to traditional men and women with regard to matters that affect their life.

\section{Views of sex}

Sexual views from African, medical and Christian perspectives are examined in order to gain a clear grasp of the phenomenon of abstinence from sexual activity during pregnancy in some African societies.

\section{African views of sex \\ Sex is a private adult affair}

Ayisi (1979:6) holds the view that some African societies regard sex as the most important factor in marriage and that therefore a premium is placed on virginity. Although the typical African world-view restricts sexual matters to a bedroom talk between husband and wife, it is very shocking that many couples still have difficulty in discussing honestly and openly the sexual challenges facing them in their marriage (Khathide 2007:78). This statement emphasises the fact that some African people are still governed by fear of talking about sexual matters to the extent that most of the sexual problems they encounter remain unsolved.

Ayisi (1979:7) argued: 'Nowadays many societies are becoming permissive and sexual intercourse is not treated as a dark secret'. This statement just confirms that, even though the culture of treating sexual matters as secret still applies to many Africans, the present trend is, that many people are gradually changing their opinions because of the influence of Western civilisation. For many cultures, including African, the main and sole purpose of sex in marriage is procreation.

\section{Sex as source of ritual impurity}

Young men and women who have not yet engaged in sexual activity participate in rain-fostering rituals in most African rural villages. The fact that the selection criterion is virginity explains the identification of ritual purity with that stage. The activities which these ritually pure young people are required to perform include running through the length and breadth of their village during the rainy season, removing those things that are thought to defile the land and impede the rain and helping the sick, together with the elderly women. About elderly women, Schapera (1979:4) says: 'Women past menopause, were also free of 'hot blood' (except when newly widowed).' Sexual activity is without doubt considered to be amongst the causes of sexual impurity amongst some African tribes. About young people who have had no sexual experience, Schapera (1979) states, citing his earlier work:

The former consisted of girls before puberty and boys who had not yet 'slept with girls' that is, those who still lacked full sexual experience. Both were regarded as 'pure' for some ritual purposes. Only they for instance, could take part in rainmaking ceremonies performed by children. (Schapera 1971:4)

Sexual activity is seen as causing ritual impurity or what Schapera calls 'hot blood'. The sidelining of those who have already engaged in sexual activity and continue to do so explains that the sexually active stage is thought to be ritually impure. This is why people in that stage do not qualify to take part in the invocation of the Supreme Being and the ancestors to bring the people rain or any other outcome for which ritual purity is of the utmost importance, e.g. helping the sick to regain health.

Schapera (1979), discussing the concept 'hot blood' (which was an equivalent of 'ritual impurity'), says:

Among the Kgatla much of everyday life, especially in matters of sex, was influenced by a concept of ritual impurity which they themselves termed 'hot blood' (madi a bollo). Basically, this consisted in the belief that on occasion a person's blood became 'hot' and then remained 'hot' for some time. While he was in that condition it was said of him, 'madi a gagwe a bollo', 'his blood is 
hot', or simply 'o bollo' 'he is hot'. Until he became 'cool' again 'a tsidifala' he was potentially harmful to other people, livestock, etc. In some cases he also ran the risk of suffering personally. He therefore had to take certain precautions, for the time being, to avert the threatened injury. Occasionally other people too had to avoid him in specified ways, either for their own sake or his. (pp. 3-4)

This 'hot blood' or ritual impurity is closely linked, amongst other things, to sexual activity, as seen above. Categorising groups that were regarded as 'hot' amongst the Bakgatla ba Kgafela in Botswana, Schapera (1979:4) points out: 'A woman was "hot" while menstruating, during pregnancy and after giving birth (until the child was taken out of the hut)'. This ritual impurity is treated by, amongst other things, the purifying ritual about which Afolayan (2004) says:

On average, children are weaned at about three years, and full sexual intercourse is forbidden between the couple until this stage is passed. Both the Mpondo and the Zulu slaughter a goat to mark the transition, purify the mother, and permit the onset of sexual intercourse. (p. 195)

This articulation justifies the argument that the pregnant woman was regarded as impure from the time of pregnancy until such time that the baby was weaned. Schapera (1979) further says, emphasising the ritually impure condition of a pregnant woman and citing his respondents Hendrik, Manyama, Rapedi and Tsholofelo, that: 'It should be noted in this connection that a pregnant woman was considered especially hot, and therefore more dangerous, in the first months of her pregnancy.' At that time, said Kgatla (Schapera 1979):
... her blood is beginning to fashion itself into a child' (Hendrik), 'her blood is fighting with the man's in her intestines' (Manyama), 'her blood is burning and not at ease' (Rapedi), 'her blood does not stay still, it is fighting in her veins to come together and form a child (Tsholofelo). (p. 4)

This should be reason enough to prohibit sexual activity with a pregnant woman who is seen as nurturing a very sacred and fragile life that needs, for its growth, ritual purity. Of course, not all Black Africans enforce sexual abstinence during pregnancy through taboos and myths. 'Taboo is a type of social rule that must not be broken. If a person breaks a taboo, even unknowingly, serious misfortune is believed to result.' (Novelguide 1999-2011). Pregnancy is a sacred life stage for those Black Africans who follow this tradition of abstinence from sex during pregnancy. This consideration may also be reason enough to exercise caution in the couple's sexual behaviour.

\section{Medical views}

Although this is a pastoral study, medical views on the issue may help us understand better whether there is the possibility of medical harm when pregnant women have sexual intercourse and even whether the practice does not deprive some of them of sexual satisfaction. It is important to point out that the medical profession has also indicated that some pregnant women become sexually more active than when they are not pregnant whereas others are sexually inactive during pregnancy. One of the medical doctors, Hlengani who was interviewed telephonically on 04 November 2011 said: 'It is a fifty-fifty situation according to me, where some women become more active during pregnancy as others become inactive.'

Apart from being a means to intimacy between the spouses and thus socially very important, there is a medical value to sexual activity during pregnancy. Shah (2011), a medical doctor, argues:

Sexual activity between the father and mother is important during pregnancy because each partner needs to feel loved and nurtured. Sex is one of the highest expressions of that love. (p. 1)

The quotations above indicate clearly that there is no medical reason to forbid pregnant women to have sexual intercourse with their husbands. According to the medical perspective, therefore, it is clear that sexual intercourse during pregnancy poses no threat.

\section{Views of sex in the Christian tradition}

The apostle Paul, in chapter seven, verses three to five, of his first letter to the Corinthians, says:

The husband should fulfil his marital duty to his wife, and likewise the wife to her husband. The wife does not have authority over her own body but yields it to her husband. In the same way, the husband does not have authority over his own body but yields it to his wife. Do not deprive each other except perhaps by mutual consent and for a time, so that you may devote yourselves to prayer. Then come together again so that Satan will not tempt you because of your lack of self-control.

In this passage, there is mutuality and equal control between the husband and wife concerning their connubial activities. It is unlike the African perspective where the couple has very little say in their conjugal rights. Whereas in the African perspective the man has more control, here Paul places the two on equal footing. Kelley (1974:385) notes in this regard: ' $[W]$ e stress the companionship of man and woman in marriage and their mutual interest and satisfaction in sexual intercourse.' Whereas in some African traditions the couple has to abstain from sexual activity for lengthy periods of time in various circumstances, here Paul insists that the two should not deprive each other [of conjugal rights], except by mutual consent for a short time of devotion to prayer, so that Satan will not tempt them. Literally, this means (Byerly \& Byerly 2011):

... do not rob, defraud, or deprive. In the Greek, the concept is that you are stealing from someone that which belongs to them. Saying no is not a case of refusing to give something, it is taking from the spouse what God says is theirs. (p. 1)

Sex in this context is not mainly meant for reproductive purposes but also to keep a husband and a wife happy and fulfilled in their life together, thereby bringing glory to God. Smith (2009) discusses the three truths about sexuality stressed in Christian tradition, namely:

... that marriage is the only proper arena for sexual activity; that marriages must be faithful for the love of spouses to thrive; and that children are a great gift to parents. (p. 2)

I would like to add a fourth truth that I consider important in this discussion: Couples do not have to deprive each other of 
sexual pleasure, which in the Christian tradition is a concrete expression of commitment to a deep bond between them. Kelley (1974) rightly asserts:

Another crucial step towards sexual harmony is commitment. The love the couple share with each other must be reinforced by responsible commitment. If either partner is not committed to give him or herself fully to the other, the union may become superficial. (p. 389)

True love can hardly exist without this requisite commitment.

\section{Abstinence from sex during pregnancy}

One of the old traditions amongst African people is that, once a woman has fallen pregnant, she is exempted from her sexual roles, since it was believed that sexual intercourse during pregnancy would harm the baby. One respondent, Ms Chauke $^{\dagger}$, said on 26 October 2011 in response to a question that:

... when an African wife falls pregnant, she is taken away from the hut or the room she shares with her husband to henceforth sleep with an elderly lady in another space.

This is confirmed in the study by Moodley and Khedun (2011) who found that:

Fifty-five women (9\%) abstained from sexual activity once pregnancy was diagnosed. Abstinence from sexual activity in our study was related to religious and traditional practices. In a meta-analysis of 59 case studies, $10 \%$ of the women abstained from sexual activity once pregnancy was confirmed, for similar reasons. (p. 35)

Mosota and Asego (2007:8) add, citing Elizabeth Ndunda about the Akamba, that 'during pregnancy a woman is prohibited from having sex with her husband, as it may cause her unborn child to have disabilities'. Popovic (n.d.:2) indicates that this belief prevailed amongst the Akamba people of Kenya. As a result of the prohibition on continued sexual activity, Mosota and Asego (2007) note: 'Men with high libidos often find themselves under pressure since they are not allowed to be intimate with their partners who are expectant or have just given birth'. It is clear from the aforementioned insights that some religious and traditional practices prescribed that women should abstain from sexual activity during pregnancy. Socio-religious factors therefore play an important role in controlling sexual behaviour, especially amongst Black Africans. These are also important determinants of the status of pregnant women in Africa and other societies (see also Adinma 1996:53).

Regarding the status of a pregnant woman in some African societies, Mbiti (1969:15) observes that in some African societies pregnant women are regarded as "impure" ritually. Because of her state of impurity she is not allowed to continue sexual intercourse with her husband'. However, the state of a pregnant woman is noted as both profane and sacred. In the state of pregnancy, the pregnant woman is considered to be both dangerous ('hot', to use the word adopted by Schapera as cited above) and a blessing: carrying life given by ancestors. For these reasons, she becomes subject to some religious beliefs related to pregnancy, and some ritual rules are expected to be observed by her and those interacting with her.

Caldwell and Caldwell's (1977:193) study distinguish four types of female sexual abstinence namely, (1) the premarital abstinence, (2) the postnatal abstinence, (3) other intra-reproductive abstinence and (4) terminal abstinence. They point out that they will pay little attention to two other common types of abstinence namely (1) abstinence during pregnancy and (2) abstinence during menstruation. Abstinence during pregnancy refers to the type with which we are concerned in this article as one of the common types of abstinence, affirming the relevance of this study.

Caldwell and Caldwell (1977), stressing the matter more succinctly, state in connection with the Nigerian situation:

The taboo on sexual relations during pregnancy is not completely accepted. However, abstinence is progressively more widely practised throughout pregnancy and few women engage in sexual relations during the last three months. (p. 196)

The question is why this is so, considering the fact cited by others (on 27 October 2011 by Ms Makhatholela ${ }^{+}$) that some pregnant women develop a greater liking and craving for more sexual action (see also Von Sydow 1999:37). Is this a question of societal undermining of women's rights or one of the social control mechanisms? Schapera (1979:6) cites the prevention of miscarriage and difficulty in labour as part of the rationale for abstinence during pregnancy.

\section{According to Labeodan (2007):}

The reason for this practice is the belief that if after conception, a woman continues to have sex with her husband, the pregnancy might be aborted, additionally, some respondents even held that the man's penis might put a dent or a hole in the baby's head. Some respondents even claimed that babies who did not cry at birth were prevented from doing so by the semen ejaculated into their mother's vagina during coitus in pregnancy. (p. 46)

This point is corroborated in the sixth sex myth and its folly (Foong Speaks Her Mind 2009): 'Sex during pregnancy may give the baby bad skin/may scare the baby/may cause the baby to have a smashed nose'. This, from a medical perspective, proves to be irrational and untrue (Foong Speaks Her Mind 2009): 'The baby is so far up and protected in the amniotic sac that whatever you do down there won't affect it.' There are, however, circumstances that may necessitate caution in terms of sex during pregnancy (Foong Speaks Her Mind 2009): 'The only danger of having sex during pregnancy is when you have pregnancy complications and the doctor advised you to abstain.' Von Sydow (1999) concurs:

The most prevalent sexual problem in pregnancy is the fear of harming the baby during sexual activity. This fear inhibits about one quarter to half of expectant mothers and at least one quarter of the men (who are sometimes afraid of hurting their partner as well). (p. 37)

This information in Foong Speaks Her Mind (2009:1) and Von Sydow (1999:37) is important, but it must be noted that the acquisition of such scientific knowledge is, in agrarian Africa, unthinkable. It should therefore be understood that 
their context is the one in which societal conduct is based on oral tradition and trusted African wisdom, norms and values. Whilst some African societies allow sexual intercourse during pregnancy, it seems to be generally agreed that couples should refrain from sexual intercourse during the last three months. This is confirmed by Ms Makhatholela ${ }^{+}$. Ms Moleko', answering the same question on 04 November 2011, said:

... in our village the time of abstinence is the last three months when elderly lady relatives take responsibility of making sure that the husband stays far from the pregnant wife.

Whilst Ms Chauke ${ }^{+}$indicates that the abstinence starts immediately when pregnancy is confirmed, the other two women place abstinence in their contexts during the last three months of pregnancy.

In Odoyoye's (1995:13) community, a woman who has given birth is described as one who has returned safely from the battlefield. This orchestrated an emphasis on the belief that pregnancy should be protected and nursed at all costs so that nothing could hinder or disturb the birth of the child. This made it easy for the pregnant mothers to avoid any disturbances, including the fear that sex during pregnancy might cause abortion. It should be emphasised that this thinking was built upon the fact that some Africans considered marriage to be valid only when children were born (though not all African tribes subscribe to this thought). This view is expressed in the saying, '[c]attle beget children' (Burman 1991:36) whilst Chigwedere (1982:7) indicates that, ' $[m]$ arriage without children had very slim chances of survival in an African context'. Mbiti (1969:133) also asserts that 'if there is not yet a child in the marriage, there is still no guarantee that the marriage will endure'.

It is for this reason that Ajai (2005:350) states that, amongst Africans, motherhood is an embodiment of respect. In the Yoruba culture the idiom Iya ni wura (mother is gold) implies that motherhood is adored and respected. Therefore since every woman would like to be adored and respected, she will try to heed the taboos which ensure her motherhood, including the taboo of avoiding sex during pregnancy. Umesao (1979) affirms this by saying:

Dotonga people in Northern Tanzania, when a woman gives birth to children, especially sons, it becomes possible for her to take charge of the cattle given to them, and to secure her position within her husband's homestead and lineage. (p. 21)

It is not the focus of this article to discuss the issues of childbirth and African philosophy surrounding it, but it is important to mention these arguments in order to indicate how the taboos and myths of exempting pregnant women from sexual encounters are built and strengthened around and upon such information.

It is surprising that the situation of abstinence from sexual intercourse does not seem to bother the abstaining women. In some instances, it has been found that some women have no problem with the lengthy periods of abstinence from sexual activity. Caldwell and Caldwell's (1977:203) study, for instance, found that, ‘[o]nly 15 percent of wives claim to miss intercourse at all' during times of abstinence. These statistics could look quite insignificant, but the authors believe that, in matters concerning the violation of gender equality and therefore of human rights, no number is too small to warrant research. The small number could be the result of internalisation of these seemingly oppressive social arrangements by these vulnerable, poor and illiterate women. It is within this frame of reference that the disparities between men and women are expressed, particularly in the context of sex.

On the positive side however, the abstinence is said to contribute to birth spacing and resultant social stability. This is stated convincingly by Okediji et al. (1976:129) who say: 'In Yoruba society, as well as in most sub-Saharan African societies, social stability was achieved by early marriage with long periods of sexual abstinence within marriage.' Even though this practice may be judged variously by today's standards, it seems to have had a positive pragmatic significance in ensuring social stability. The question however is whether this social stability must be pursued even at the expense of commitment that ensures fidelity in the family. How can social stability be built on family infidelity and instability? The authors believe that family fidelity is a good foundation for social stability.

\section{Critical evaluation}

This practice of abstinence during pregnancy does not only exclude women from sexual activities, but it also gives men an excuse to have sex with other women outside of wedlock. That is why even the elders of the village, who see to it that every family is run properly, will allow the man in this situation to have other women outside of his marriage in order to satisfy his sexual desires. That is why, in the same vein, Labeodan (2007:47) says: 'This might lead to polygamy, while most women interviewed were made to believe that they must accept the situation as it is'. Lawoyin and Larsen (2002:56) are in agreement when saying: 'In general, more men had other sexual partners when the wife was pregnant (43.7\%) compared with the period outside pregnancy (42.1\%).' In that way, the gender inequality became more evident since the women did not receive the same privileges of having multiple relationships with men. This is corroborated by Mitsunaga et al. (2005) who note:

In Nigeria and in other regions of sub-Saharan Africa, it is widely believed that men are biologically different from women in their need for sex. This has resulted in the perception that men may have unlimited sexual freedom, whereas women are expected to be faithful to only 1 partner at a time. (p. 479)

It can be argued that this is an outmoded polygamous mentality which is revealed when extra-marital sex is justified on the grounds that men are allowed to look for another wife or concubine whereas women must remain faithful. Shorter (2001:92) argues that this double standard ideology brings about the imbalance between genders.

It has always been said that avoiding multiple relationships is one of the ways in which the spread of sexually transmitted 
diseases can be reduced. Mitsunaga et al. $(2005: 478,488)$ state in this regard: "The "zero grazing" theory (sticking to one sexual partner)' is one of the three (ABC) strategies that need to be employed in preventing the spread of the HI virus. The argument then arises whether the issue of preventing HIV will be effective when a man has multiple sexual relationships, which will in the end put his family, particularly his wife, at risk whenever she rejoins him sexually. That is what Masenya (2005:190) means when she notes: 'It thus makes sense that many African women are becoming easy prey to the HI-virus'. This argument becomes weightier when considering the extent to which it leads to children being orphaned, which seems to be escalating in South Africa. In her aptly titled book Children of AIDS: Africa's orphan crisis, Guest (2003) writes, citing Frances, the social worker at the orphanage called Beautiful Gate:

Staff at orphanages know that they're working against the tide. They acknowledge that they should be the last resort, but firmly believe that children's homes have an important role to play in the coming AIDS orphans crisis. (p. 89)

The social worker can deduce from the current trends that there will, in the near future, be an increase in the phenomenon of AIDS orphans.

The practice under discussion is part of African customs that need to be read in the light of the African patriarchal system, which has always promoted the domination of the male gender over the female. Nadar (2009) is correct in saying:

Understanding the ways in which male power is created and maintained, is a crucial link in overcoming patriarchy together with all its associated evils such as violence, because numerous studies have shown, at the heart of violence against women is male power. (p. 553)

Patriarchy as a wrongly accepted perpetuation of gender inequality which is one of the worst injustices that deserves to be fought without reservation. Writing in the context of the HIV infection threat and the need for prevention strategies and for the respect of human rights, Latré-Gato Lawson (1999) says:

... it will be impossible to introduce the fundamental changes required to master this pandemic so long as the interrelations between HIV-positive status, medical factors, cultural and social values and human rights are not fully understood. (p. 391)

For a long time, patriarchal domination has caused women to be treated as inferior people whose only duty was to blindly take instructions from men. It is in this context that the authors are in accord with Mbeya (1994:26) that any aspect of African culture which keeps women in bondage or reinforces their inferiority (like women's exemption from sex during pregnancy) should not only be critiqued but should also be challenged and denounced. Louw (2009:425) is of the opinion that love-centred sexual ethics is inseparable from reconciliation and justice. Hence the focus of sexual activities should be mutual empowerment rather than dominance and exploitation. In this way, sexual love will include mutuality and is other-enriching and other-empowering, showing concern for the well-being and growth of the partner or spouse, which is not the case in the African view mentioned above.
It also becomes a gender-sensitive issue when one gender is excluded from sexual encounters whilst the other gender is allowed to have sexual intercourse even outside of marriage. That is how patriarchy managed to use the taboos and myths from African culture to oppress women whilst liberating men at the same time. It is for this reason that Moore (1999:194) argues that the restrictions imposed on pregnant women cause them to be referred to as 'closed' women (bungaroocheanda in Tanzania), pointing to their physical bodies being closed in the sense that they do not even menstruate during pregnancy. An United Nations (UN) resolution indicates that the control of female sexuality by men and the economic and political subordination of women by men perpetuate the inferior status of women and inhibit the structural and attitudinal changes necessary to eliminate gender inequality (UN 1979:2). Postmodern people are warned not to view women as unequal as they are people with human rights like everybody else.

The information that was gathered from the medical viewpoints does not support the notion that sexual intercourse may cause harm to either the conceived baby or its parents. Therefore this falsifies the premises of those who use health-related excuses as reason for forced abstinence, and it reinforces the opposite view. This exposes the fallacy that men are more equal than women and will hopefully eliminate the cases of men having extramarital affairs and polygamous marriages as a result of the belief in the need for abstinence from sexual activity during pregnancy. It is interesting that, though the Lobedu are Africans, their view of the issue is different. According to Tyrrell (1983:103), although they are aware of the belief held by other tribes, for them, continued intercourse is necessary to provide enough male semen to mould or vitalise the foetus. We can learn from this that not all African tribes subscribed to the same thought. The unfair part of the story is that, just as Masenya (2005:188) noted, women always have to be available for the sexual gratification of their spouses, although the opposite is not the case. In this way, the authors agree with Ngubane who articulates that women are viewed as the property of men, first of their fathers, then, when they get married, of their husbands. This serves to encourage male dominance as well as to increase and encourage violence against women (Ngubane 2010:2). This is without doubt a human rights violation that needs to be crushed without mercy. There is therefore a dire need for pastoral attention to the victims and perpetrators of this oppressive African traditional sexual conduct.

\section{Pastoral care guidelines and focus}

Griffin (1995:24) summarises his discussion of pastoral care thus: 'Pastoral care is the church's response, in obedience to the Gospel, to the needs of others'. Pastoral care is in this way, (without implying that it is the only response of the church) important in our need to address the needs of sexually deprived African women in situations like those described above. The traditional functions of pastoral care are healing, sustaining, guiding and reconciling (De Jongh, Van Arkel 
1999:135-141). Our subsequent attempts are meant to assist in addressing the dire situation that was described in earlier parts of this article with the hope that they will comfort and empower the vulnerable traditional women and facilitate the cause of gender equality and transformation.

The authors' practical theological approach is the correlational approach which is concerned with the critical theological reflection on the theory-praxis dialectic (cf. Ackermann 1993:21; Manala 2006:40). In this paradigm, the authors are in accord with Pieterse (1998:181) that text and context permanently evoke each other resulting in new light being shed on the actual situation. In pastoral care, the bipolar tension between text and human reality is important. Louw (1998:8) talks in this regard of convergence or an integrated model which takes into serious consideration theory and practice in which the basic theological theory for pastoral care (operates) from an eschatological and pneumatological perspective'. The message of salvation through Christ's death and resurrection is mediated and sealed by the Holy Spirit in the life of the people receiving care. This is the model in which the authors of this article situate themselves. It is a dialogical approach at the centre of which is the covenantal dimension. The relationship is central in this model.

\section{Pastoral caregivers should give counselling to couples}

In this article, the concept pastoral caregivers is used to refer to pastors who are involved in the church as well as in helping the community. Pastoral caregivers should be emphatic about the need for intimacy between couples at all times, as noted by the apostle Paul in 1 Corinthians 7:5. The principle that couples should cleave together should be communicated clearly during premarital and ongoing marriage counselling. This clearly contradicts the African rules prescribing abstinence during pregnancy and other occasions which, in many ways, lead to extramarital sex by husbands and which could result in the transmission of HIV. It could also lead to polygynous marriages with their devastating consequences for true spousal commitment, the economy and population growth. Latré-Gato Lawson (1999:393) rightly points out: 'However, the present tendency of the epidemic to spread can be attributed to general sociocultural factors which place women in a particularly vulnerable position.' A new perspective that is devoid of stringent prescriptions regarding sexuality should be introduced in our African socio-religious environments. Amadiume (2007) notes:

A perspective that encourages discourse on responsible sexuality without guilt, fear or ill-health is a welcome and courageous departure from stasis and regression that typify rigid orthodoxies or suffocating normativity. (p. 1)

Transformation is required to avoid the insinuation that women are not human. Various literature sources, including the Bible, should form part of the information presented to Christian and interested African couples in preparation for and fortification of their marriages. In this regard, the church and especially her services should be extended to both Christian and non-Christian communities.
It is part of the duty of pastoral caregivers during family counselling to make the couples aware that there is no harm when partners continue with sexual intercourse during pregnancy although medical doctors can also offer this advice. If couples need more information, they can also be referred to a medical doctor for explanation. Medical doctors always conduct medical examinations on the expectant mothers to explain and give medical advice if they happen to find some complications. It is an advantage of civilisation that pregnant women always undergo certain clinical and medical examinations before delivering the baby, and this opportunity can be used to encourage men to accompany their wives to those sessions so that nurses and doctors can explain the details about whether sex will be harmful or good for them during the pregnancy. Pastoral caregivers should take the responsibility to persuade women to convince their husbands to accompany them.

\section{The African Christian church's responsibility}

Although the mission of the church is primarily to preach the Gospel, it is also good for the church to speak to people about matters related to sex, particularly from a biblical perspective. That is why the authors agree with Pastor Manganyi Strike, who mentioned in a radio presentation on 06 November 2011 between 6 am and 7:30 am that there are three important phases in marriage: pre-marital counselling, post-marital counselling and family counselling during the course of life. In the same vein, Baloyi (2010:5) emphasises that the church must not shy away from teaching about the sinfulness and the consequences of sexual relationships outside of marriage. These include HIV and AIDS, unwanted pregnancies and so forth. Sex is a wonderful gift that God gave to humankind for the sake of their marital relationships but only when it is enjoyed in marriage. Sex education is very important not only to young people who are still to get married but also to older people who did not have an opportunity to learn about sex from other contexts than their own culture. The argument here is that sexual intercourse is a universal phenomenon, hence knowing it only from an African perspective deprives traditional people of attaching a positive meaning and intention to it. It is truly a difficult task to convince traditional people who have internalised the taboos and myths regarding abstinence from sexual relationship during pregnancy, but it should start with the present generation and anyone who is ready to help to explain the disadvantages of those taboos. Folkman and Clatworth (1970:140) argue that a loving husband and wife who enjoy a satisfactory sexual relationship are likely to have a happy marriage and to produce a happy home for their children.

\section{Women's responsibilities}

Although some still understand sexual intercourse as a private matter between two partners, women are responsible to indicate to their husbands that it is also a human rights issue. They should not keep quiet when they feel they need it, but they should talk to their husbands and inform them about their feelings. The authors believe that culture is dynamic, 
hence changing, reshaping and correcting wrongs of the past from within does not mean that people's right to preserve and sustain their culture is taken away from them. The aim is rather to ensure that the very same rights are not used to abuse others as well as to promote gender inequalities. It is indeed not a question of destroying traditions but of reshaping and correcting them so that they cannot be used to deny and abuse women, who are also human beings with rights, even in sexual matters. Although she acknowledges that, in terms of many African cultural values, marriage and sex are for procreation, Kimathi (1994:40) argues that marriage is also intended for friendship between spouses. The authors agree with Maluleke and Nadar (2002:16) that transforming women's silence requires the conversion and intensification of their thoughts of resistance, as well as their weak, often counterproductive and incoherent survival strategies into a growing self-confidence as little by little, they gain more and more ground. It sometimes becomes very difficult even for the pastoral caregivers to discuss matters of sexual concern with traditional Africans who are still inclined to shy away from it, and in that case, women should be ready to help themselves. They also need to break their silence because keeping quiet also exposes them to exploitation. Information about males' sexual world as well as women's sexual world is very important for the couple's sexually healthy lifestyle, for instance, that both men and female experience sexual desire but male and female sexualities are not the same (Folkman \& Clatworth 1970:118).

\section{Helping traditional people to consider medical advice}

It is also a challenge to help a traditional person understand the importance of medical advice, and therefore our communities still have elderly people who refuse to be taken to hospitals when they are sick, citing their fear of death in hospital. However, it is pleasing that many of those people at least agree to visit private medical practitioners and clinics, which can also be used as an opportunity.

Without being negative towards people's culture, traditional pastoral caregivers should give advice to traditional women. People must be educated concerning this important matter. That is why Folkman and Clatworth (1970:115) advocate the importance of sex education where men and women's worlds can be explored and explained. Amadiume (2007) notes in this regard:

Criticism can be combined with education that points out gender oppression in the various theologies and reveals those positive messages that can arm the oppressed with subversive knowledge for challenging systems of oppression. (p. 7)

We agree with Amadiume (2007) that:

We need to work with a broad perspective that subjects the rigidity of the normative to a critical evaluation that presents a more progressive alternative in the face of the challenges of social change. (p. 9)

\section{Conclusion}

The African patriarchal system resulted in, amongst other things, the unconditional subordination and oppression of women in many spheres of life, including sexual life. It is because of society's view that women are secondary citizens that women have internalised even the male-dominated ideas which oppressed them for the sake of pleasing men. The taboos and myths are often used to silence women for whatever unjust reason, and this might cause the humiliation and subordination of women. Sexual activities, in particular, have been used as weapons to ensure that women are always under the control of men. That is what Phiri (2002:24) means by saying that sex is used as a weapon of domination. These attempts always aim at putting the male figure into a position of authority because all arguments would support the notion that a man should be allowed to have multiple relationships whilst the woman should wait for one man only. It also victimises women and children in the sense that, if during the time of pregnancy the man would be infected with HIV where he was having extramarital sex, his return to his wife when the child has been weaned would automatically mean that he is also going to infect his wife. It is clear that the taboos and myths attached to barring women from sexual intercourse during pregnancy are at times not only questionable but also non-valid from both theological and medical points of view. The more sex education takes place, the less these kind of situations will prevail.

\section{Acknowledgements Competing interests}

The authors declare that they have no financial or personal relationship(s) which may have inappropriately influenced them in writing this article.

\section{Author contribution}

Both authors were responsible in every section of the article. Of course, at certain sections, one author's contribution would be more pronounced. However, the authors generally worked together. This was done by way of changing whatever each author had written. The authors met on several occasions to discuss and co-ordinate the work.

\section{References}

Ackermann, D.M., 1993, 'Critical theory, communicative actions and liberating praxis: Views of a feminist practical theologian', Journal of Theology for Southern Africa 82, 21-36.

Adinma, J.I.B., 1996, 'Sexual activity during and after pregnancy', Advances in Contraception 12, 53-61. http://dx.doi.org/10.1007/BF01849546, PMid:8739516

Afolayan, F., 2004, Culture and customs of South Africa, Greenwoods Press, London. PMCid:2568537

Ajai, S.A. (ed.), 2005, African culture and civilization, Atlantis Books, Ibadan. PMid:16014700

Amadiume, I., 2007, 'Sexuality, African religio-cultural traditions and modernity: Expanding the lens', viewed 20 October 2011, from http://www.arsrc.org/ downloads/features/amadiume.pdf

Ayisi, E.O., 1979, An introduction to the study of African culture, 2nd edn., East African Educational Publishers, Nairobi.

Baloyi, M.E., 2010, 'An African view of women as sexual objects as a concern for gender equality: A critical study', Verbum et Ecclesia (31)1, 1-6.

Boonzaier, E. \& Sharp, J. (eds), 1988, South African keywords, The uses and abuses of political concepts, David Philip, Cape Town. PMid:3365047

Burman, S., 1991, 'Illegitimacy and the African family in a changing South Africa', Acta Juridica 21, 36-51.

Byerly, P. \& Byerly, L., 2011, 'Sexual responsibility A look at 1 Corinthians 7 In the marriage bed - sex and intimacy for married Christians', viewed 25 October 2011, from $\mathrm{http}: / /$ site.themarriagebed.com/1-cor-7-sexual-responsibility 
Caldwell, J.C. \& Caldwell, P., 1977, 'The role of marital sexual abstinence in determining fertility: A study of the Yoruba in Nigeria', Population Studies 32(2), 193-217. http://dx.doi.org/10.2307/2173915

Chigwedere, A., 1982, Lobola, Books of Africa, Harare.

De Jongh van Arkel, J.T., 1999, 'CGM112-P, Part 4: Care', in J.P.J. Theron, M.E. Hestenes \& J.S. Dreyer (eds.), First steps in Practical Theology, pp. 112-152, University of South Africa, Pretoria.

Folkman J.D. \& Clatworth, N.M., 1970, Marriage has many faces, Charles E. Marrill Publishing Company, Columbus.

Foong Speaks Her Mind, 2009, Hitting and scoffing at more stupid superstitions and pregnancy myths, viewed 27 October 2011, from http://foongsite.com/index. php-/2009/07/hitting-and-scoffing-at-more-stupid-superstitions-and-pregnancymyths

Griffin, G.M., 1995, Coming to care: An introduction to pastoral care for ordained ministers and lay people. The National Library of Australia Cataloguing-inministers and lay people,
Publication, Melbourne.

Guest, E., 2003, Children of AIDS: Africa's orphan crisis, 2nd edn., University of Natal Press, Pietermaritzburg.

Kelley, R.K., 1974, Courtship, marriage and the family, 2nd edn., Harcourt Brace Jovanovich, Inc., New York.

Khathide, A.G., 2007, Bone of my bones, Building marriages that work in Africa, AcadSA, Kempton Park.

Kimathi, G., 1994, Your marriage and family, IRS, Potchefstroom.

Labeodan, H.A., 2007, The Yoruba belief system and its impact on women's reproductive health, Journal of Constructive Theology 13(1), 39-55.

Latré-Gato Lawson, A., 1999, 'Women and AIDS in Africa: Sociocultural dimensions of the HIV/AIDS epidemic', International Social Science Journal 161, 391-400. http:// dx.doi.org/10.1111/1468-2451.00207

Lawoyin, T.O. \& Larsen, U., 2002, 'Male sexual behaviour during wife's pregnancy and postpartum abstinence period in Oyo State, Nigeria', Journal of Biosocial Science 34, 51-63. PMid:11814213

Louw, D.J., 1998, A pastoral hermeneutics of care and encounter: A theological design for a basic theory, anthropology, method and therapy, Lux Verbi, Cape Town.

Louw, D., 2009, 'Sexual violence: From abuse (power) to sacrament: Towards the sanctification of the genitals in a pastoral hermeneutics', Scriptura 102, 416-429.

Maldonado, M., n.d., Cultural issues during pregnancy, viewed 26 October 2011, from http://www.authorstream.com/Presentation/Stentore-41340-cultural-issuesduring-pregnancy-Culture-general-as-Education-ppt-powerpoint/

Maluleke, T.S. \& Nadar, S., 2002, 'Breaking the covenant of violence against women', Journal of Theology of Southern Africa 144, 5-17.

Manala, M.J., 2006, 'The church's ministry to the sick in a black African context', PhD thesis, Dept. of Practical Theology, University of South Africa.

Masenya, M., 2005, The Bible, HIV/AIDS and African-South African women: A bosadi (womanhood) perspective', Studia Historiae Ecclesiasticae 31(1), 187-201.

Mbeya, C.M., 1994, 'A voice from Zaire', Atlas Serials Spring, 25-27.

Mbiti, J.S., 1969, African religions and philosophy, Praeger, New York.

Mitsunaga, T.M., Powell, A.M., Heard, N.J. \& Larsen, U.M., 2005, 'Extramarital sex among Nigerian men: Polygyny and other risk factors', Journal of Acquired Immune Deficiency Syndromes 39(4), 478-488. http://dx.doi.org/10.1097/01. qai.0000152396.60014.69, PMid:16010173
Moodley, J. \& Khedun, S.M., 2011, 'Sexual activity during pregnancy: A questionnairebased study', South African Epidemiology Infect 26(1), 33-35.

Moore, S.K., 1999, Those who play with fire: Gender, fertility and transformation in East and Southern Africa, The Athlone Press, London.

Mosota, M. \& Asego, N., 2007, 'World traditions: Myths and taboos - should we believe them?', African Press International (API), viewed 04 October 2011, from http://africanpress.me/2007/10/01/myths-and-taboos-should-we-believe-them

Nadar, S., 2009, 'Palatable patriarchy and violence against women in South Africa - Angus Buchan's mighty men's conference as a case study of masculinism', Scriptura 102, 551-561.

Ngubane, S.J., 2010, 'Gender roles in the African culture: Implications for the spread of HIV/AIDS', Unpublished MA thesis, University of Stellenbosch.

Novelguide, 1999-2011, 'Taboo and sin', viewed 09 November 2011, from http:// www.novelguide.com/search/google/Taboo\%20and\%20sin?query=Taboo\%20sin \&cx=014594894019114723871\%3Ajichblhs364\&cof=FORID\%sitesearch=

Odoyoye, M.A., 1995, Daughters of Anowa: African women in patriarchy, Orbis, New York.

Okediji, F.O., Caldwell, J., Caldwell, P. \& Ware, H., 1976, 'The changing family project: A report with special reference to Nigeria Segment', Studies in Family Planning 7(5), 126-136. http://dx.doi.org/10.2307/1964857, PMid:936262

Osei, J., n.d., 'The value of African taboos for biodiversity and sustainable development', viewed 27 October 2011, from http://www.jsd-africa.com/Jsda/ Fall2006/PDF/Arc_the\%20Value\%20of\%20Arican\%20Taboos.pdf

Pieterse, H.J.C., 1998, 'A theological theory of communicative actions', Religion \& Theology 5(2), 177-194. http://dx.doi.org/10.1163/157430198X00048

Phiri, I.A., 2002, 'Why does God allow our husbands to hurt us? Overcoming violence against women', Journal of Theology for Southern Africa 114, 19-30.

Popovic, M., n.d., Traditions and customs from all over the world, viewed 20 November 2011, from http://traditionscustoms.com

Schapera, I., 1971, Rainmaking rites of Tswana tribes: Leiden, Afrika-studiecetrum, Afrcan Social Research Documents, (3), 72-73, 76-81, 84-85.

Schapera, I., 1979, 'Kgatla notion of ritual impurity', African Studies 38(1), 3-15, viewed 27 October 2011, from http://www.tandfonline.com/doi/ pdf/10.1080/00020187908707528

Shah, R., 2011, 'Sex during pregnancy', viewed 04 November 2011, from http://www. indiaparenting.com/pregnancy/121_2984/sex-during-pregnancy.html

Smith, J.E., 2009, 'The Christian view of sex: A time for apologetics, not apologies, At one more soul', viewed 25 October 2011, from http://www.catholiceducation. org/articles/sexuality/se0004.html

Shorter, A., 2001, African culture - an overview, Paulines Publications Africa, Nairobi.

Tyrrell, B., 1983, African heritage, Macmillan South Africa, Braamfontein, Johannesburg.

Umesao, T. (ed), 1979, Senri Ethnological Studies No 1, Africa 1, National Museum of Ethnology, Kyoto, Japan.

United Nations, 1979, Fact Sheet No 23, Harmful traditional practices affecting the health of women and children, Convention on the elimination of all forms of discrimination against women (art. 5(a)), adopted by General Assembly Resolution 34/180 of 18 December 1979, OHCHR publications, Geneva, Switzerland.

Von Sydow, K., 1999, 'Sexuality during pregnancy and after childbirth: A metacontent analysis of 59 studies', Journal of Psychosomatic Research 47(1), 27-49. http:// dx.doi.org/10.1016/S0022-3999(98)00106-8 